\title{
Merchant Benefits and Public Policy towards Interchange: An Economic Assessment
}

\author{
MARGARET E. GUERIN-CALVERT * \\ President and Managing Director, Competition Policy Associates, Inc.
}

\author{
JANUSZ A. ORDOVER
}

Professor of Economics, New York University and Director, Competition Policy Associates, Inc.

\begin{abstract}
We analyze the complex nature of interactions among participants in "two-sided" payments system markets, examine empirical evidence on benefits, especially merchant benefits, and re-assess the role of interchange in balancing interests and allocating costs between merchants and consumers. We conclude there are substantial potential harms to payments systems, consumers, and merchants from imposing cost-based regulation of interchange fees, particularly with network fixed costs. Competition policy, in our view, is the best prescription - through government intervention under the antitrust laws or private challenges to exclusionary strategies that hamper competition to the detriment of cardholders, merchants, and competing networks.
\end{abstract}

\section{Introduction}

Regulators in many countries are taking an active interest in the operations of credit and debit card networks. ${ }^{1}$ A good deal of attention is being paid to the issue of the interchange fees which are set by credit and debit card networks and paid by merchants. ${ }^{2}$ The regulators have questioned the mechanisms by which these fees are set, their levels and changes in their levels, and are evaluating a broad range of public policy responses to various perceived problems relating to interchange fees as well as other features of credit card payments networks. Both the sources of concern and the potential policy responses have varied across jurisdictions:

\footnotetext{
* Contact Author. Competition Policy Associates, Inc., 1919 Pennsylvania Ave NW, Suite 780, Washington, DC 20006, U.S.A. Phone: (202) 293-2626. E-mail: mguerin-calvert@competitionpolicy.com

${ }^{1}$ We use the terms "payments network" or "payments systems" to denote both credit and debit card networks.

${ }^{2}$ Multilateral interchange fees (MIF) are fees paid by merchant acquiring banks to the credit (debit) card issuing banks. Merchants pay merchant discount fees (or merchant service charges) which include the interchange fee payable to the issuing bank. Under the Visa/MasterCard model, the interchange fees are collected from the merchants by the acquiring banks and passed on to the cardholders' banks (the issuing banks). Proprietary networks, such as American Express or Discover, do not set interchange fees since they function both as merchant acquirer and a card issuer. The proprietary networks directly collect fees from the merchants as the price of card acceptance.
} 
- In some jurisdictions, the focus of concern has been on the collective fee-setting aspect of interchange fees. In contrast, the European Commission has accepted that some type of collective agreement regarding the fees may provide efficiency in a network of "thousands" of member banks (Ryan, 2002). ${ }^{3}$ The Commission has also rejected arguments that interchange fees are a pure tax on retailers and should be set at zero and, instead, has indicated that such fees do in some way compensate for and make possible provision of beneficial services to retailers.

- Nonetheless, precipitated in large part by merchant complaints, various regulatory bodies have evidenced concern that the levels of interchange fees are "too high" relative either to the costs of services provided to merchants or to the perceived benefits obtained by merchants from card acceptance. ${ }^{4}$ Policy tools used or under consideration include direct regulation of the fees that a network may charge to merchants or consumers. ${ }^{5}$

This growing interest among policymakers outside the U.S. favoring some form of costbased regulation of interchange fees is particularly surprising given that numerous economic analyses have called into question the need and desirability of such regulation of payments systems. In particular, many researchers have pointed out that in two-sided markets, as exemplified by credit and debit card markets, the role of fees paid by participants on each side of the market is multi-faceted and may involve an element of cross-subsidy. ${ }^{6}$ In twosided markets, the total volume of transactions - as well as the share of transactions effectuated by different payments instruments - and the concomitant total level of economic benefits that accrue to the participants depend in part on how the responsibility for the recovery of the total costs of the network is allocated. The network externalities that link merchants who accept cards and card-holders who use them compel a price/fee structure that will likely entail deviations from the cost-causality principles that call for prices to be closely linked to the underlying costs of providing direct benefits to either side of the market. ${ }^{7}$

\footnotetext{
${ }^{3}$ Thus, the European Commission has accepted that "some kind of default agreement on the terms of exchange between issuing banks and acquiring banks is necessary in practice in a large-scale international payment system, as without it bilateral negotiations between many thousands of banks would be highly inefficient and increase costs significantly." Ryan (2002).

See, for example, Schmalensee (2002).

${ }^{4}$ For example, in its decision regarding Visa's cross-border interchange fees, the Commission questioned whether the level of cross-border interchange fees was set to reflect the services (benefits) provided and the costs of providing such services and more importantly, whether these interchange fees reflected a reasonable and equitable balance of payments between cardholders and retailers. See, EU Institutions (Jul. 27, 2002). Recent articles such as that by Hayashi (2004) propose a narrower focus of the benefit/cost analysis of fees to include the transaction-specific benefits to the merchants, thereby suggesting an imbalance between costs and benefits.

${ }^{5}$ For example, Reserve Bank of Australia (2003) reforms required Visa/MasterCard interchange to be reduced to a cost-based level; and the European Commission (2002) decision required Visa to reduce its cross-border credit and debit card interchange. See also Gans and King (2003) for a careful review of the various regulatory proposals.

${ }^{6}$ See, for example, Evans and Schmalensee (2005).

${ }^{7}$ The price structure of credit card networks reflects the balancing of participations and interests of cardholders and merchants. The benefits to network participants are intertwined and dependent on the overall network size, vibrancy, and growth in the number of participants on each side of the market. In this respect, "prices" to cardholders cannot be set too high (with prices to merchants being too low) or cardholders will not want to carry the card, and prices to merchants cannot be set too high (with prices to cardholders too low) or merchants will not want to accept the card. However, economic analyses show that with some special assumptions, the level of the interchange has no relevance for real economic variables which are of interest to the regulator.
} 
This accelerating focus on cost-based regulation of interchange fees is also quite perplexing in view of the common recognition among economists and policy makers that heavy-handed price regulation is rarely desirable and risks unintended consequences (such as suppression of incentives to invest and innovate, and shifting of cost burdens to consumers) that can distort markets. ${ }^{8}$ It is also directly at odds with the broadly accepted principle that competition policy is a superior means to address perceived inefficiencies in the marketplace. In most market contexts - including in the credit and debit card industry - there has been an express preference for the use of antitrust enforcement "toolbox" as the means to address the non-competitive pricing, barriers to entry, or other impediments to competitive functioning of the marketplace in order to achieve efficient functioning of markets. ${ }^{9}$

The trend toward direct regulatory intervention is thus questionable given the recognized complex inter-relationships between network-level investments, card usage, and delivery of benefits, and the nascent stage of empirical work on estimates of benefits to merchants from debit and credit card networks. Much of the available literature and policy pronouncements define "benefits" to merchants very narrowly and tends to focus primarily on transactional gains, thereby omitting from the assessment any broader benefits that are provided by credit card and debit card networks or the complex mechanisms involved that generate the benefits. In our view, the benefits to merchants from card acceptance cannot fairly be analyzed solely on the basis of savings in per transaction costs. Benefits that extend beyond pure transactional or processing efficiencies from card acceptance include broader operating efficiencies, payment guarantees, reduced risks of theft of cash, elimination of the risk of uncollectible checks, the gains from efficient resolution of customer disputes through the credit card network chargeback processes, access to (and benefits from) network marketing programs, and improvements in merchants' cash flow. For example, in a credit card transaction, the merchant will be paid well before the card issuer receives payment from the card holder, which reduces operating cash balances that a merchant needs to have on hand. If, instead of accepting a credit card, the merchant were to extend credit to the customer, the merchant would have to incur the cost of a credit check, wait for payment and bear the risk that the customer might not pay. By accepting the credit card, the merchant gets the benefit of prompt payment, while the card issuer bears the cardholder credit and fraud risk. It is not at all clear that these complex bundles of benefits can be neatly converted into a "per transaction" benefit with a well-calibrated cost easily assignable to the transaction. In fact, the "production" and delivery of these benefits by payments networks require complex coordination, large fixed (and sunk) investments, sustained participation of merchants and cardholders on the network, and fee and price schedules that stimulate transaction volumes and create incentives for product and service innovations. Moreover, because the "benefits" to each side of the market - merchants and cardholders - are intertwined, any regulated apportionment of costs or fees, risks being completely arbitrary.

The purposes of this paper are to analyze "two-sided" markets, including the complex nature of interactions among the various participants in the payments system markets, and to

\footnotetext{
${ }^{8}$ See, for example, Gonenc, Maher and Nicolette, (2000); Schmalensee and Willig, particularly Part 5Government Intervention in the Marketplace; see also, Morrison and Winston (1995) and Department of Justice.

${ }^{9}$ By "antitrust toolbox" we refer to the variety of tools available to private parties and government agencies to address specific competition policy concerns related to business practice, artificial restraints on entry, or merger effects. See, for example, US v. Visa and MasterCard, retailer litigation concerning debit cards (In re Visa check-MasterMoney), and recent merger investigation by DOJ into the proposed EPS/ Concord merger. United States Court of Appeals for the Second Circuit (Aug. 2002) United States of America v. Visa USA, Inc., Visa International Corp., and MasterCard International, Inc.
} 
examine the empirical evidence on the benefits of payment systems, particularly the evidence with regard to merchant benefits. Taking these benefits into account, we re-assess the role of interchange in balancing the interests and allocating costs between merchants and consumers and the complexities of the multi-sided credit card market. Based on this analysis, we conclude that the potential harms to payments systems, consumers, and also retailers from imposing cost-based regulation of interchange fees are substantial and require careful public policy assessment. In particular, it is our view that the preferred policy is to ensure that market-place features that promote effective competition among providers of payments systems are enhanced and, if deemed inadequate, are strengthened so as to generate ultimate benefits to merchants and consumers. Thus, the most sensible policy prescription, in our view, is to rely on the available tools of competition policy, be it through government intervention under the antitrust laws or private challenges to exclusionary strategies that hamper competition to the detriment of cardholders, merchants, and competing networks.

This paper is organized in three sections. Section II sets the context for evaluation of proposed regulation and provides an overview of antitrust policy toward debit and credit card networks. Section III assesses the benefits from debit and credit card networks, and focuses particularly on empirical evidence on the benefits to merchants, the sources of these benefits, and the related network investments. Section IV provides an assessment of the economic rationale for price regulation and concludes that reliance on the competition policy "toolbox" provides a superior policy approach to address impediments to competition in payments markets.

\section{Antitrust policy: Setting the stage for the relevant policy approach}

Economic theory and experience demonstrate that promotion of vigorous competition, not price regulation, is generally the most effective way of delivering benefits to all market participants. ${ }^{10}$ A competitive and efficiently operating marketplace generally provides the necessary constraints to ensure that "prices" are set with regard to costs and in a manner that reflects the benefits that are provided.

Appropriately designed competition or antitrust policy needs to take into account the twosided nature of the payments systems. In fact, even those who recommend that interchange price regulation could be a desirable policy, point to the complexity and potential disruption that could arise from such regulation. ${ }^{11}$

Efficient functioning of payments markets requires complex coordination of the interests of consumers (as cardholders) and merchants. What this means is that, for a particular form of payment (or a credit or debit network) to be a feasible competitive alternative to the existing means of payment (or other networks), the network must gain acceptance on both sides of the market. This means that consumers must be willing to acquire and use that card while merchants must be willing to accept it. This "two-sided" coordination problem is particularly complex because each side of the market exerts a type of network externality on the other side. This means that the ability to persuade potential cardholders to acquire and use

\footnotetext{
${ }^{10}$ See, references in footnote 9 as well as Breyer (1982).

${ }^{11}$ In a recent speech, John Vickers, Chairman of OFT, presents a view that regulation of interchange within a broad band of permissible costs or range of fees could arguably be workable in "mature" payments markets, but then goes on to indicate that this conclusion is dependent on such intervention not disrupting market operation and investments and recommends such policy only in the absence of effective antitrust enforcement policy tools. See Vickers (2005). However, neither Vickers nor the literature cited indicates that there is a compelling case on this basis for regulation (or rejects fact that regulation is costly). Indeed, most notably, Vickers notes that empirical evidence on merchant benefits and investments by networks is limited.
} 
the card depends on the number of merchants who are willing to accept the card; and the ability to persuade the merchants to accept the card depends on the number of cardholders who are willing to acquire and use the card. At the same time, the network must attract a sufficient number of issuers to issue cards and must create incentive for banks to invest in the process of acquiring merchants. Hence, the growth in the number of participants on each side of the market can engender a "virtuous cycle" that requires careful balancing and rebalancing of incentives provided to the market participants.

In the two-sided market, competition among various payments platforms (and among providers of these payments platforms) takes the form of simultaneous vying for merchants and vying for cardholders-qua-consumers (or consumers-qua-cardholders). Any network's need to deal simultaneously with both sides of the market creates a potential conflict of objectives: On the one hand, given the number of that card's cardholders, merchants are more likely to accept a given card (or means of payment) if they are charged "as little as possible" whenever a customer uses a given card. On the other hand, holding the number of merchants who take the card constant, a credit cardholder would like to be charged "as little as possible" for acquiring and using the card. ${ }^{12}$

Since credit card networks have considerable fixed and variable costs associated with the development, deployment, maintenance, and operation of the network, they cannot simultaneously charge both sides of the "market" nothing (or "as little as possible"). Moreover, given the network externalities elucidated above, pricing to one side of the market affects (spills-over into) the incentives on the other side. At the most basic level, the interchange acts as a mechanism for shifting per transaction costs from one side of the market to another (from acquirers to issuers, for example) given that in the two-sided markets competitive success depends not only on the overall level of fees but also on the structure of the fees imposed on each side of the two-sided market (Ryan, 2002). ${ }^{13}$ The diagram below (Figure 1) sets out the economic flows of payments and benefits between merchants, cardholders, and the network. The diagram depicts the flow of funds from cardholder to issuer to acquirer to merchant in exchange for the purchase, which moves from the merchant to the cardholder. As shown on the diagram, the flows of benefits in the two-sided setting is complex, as these benefits are being conferred by cardholders on the merchants and vice versa in a relationship that is mediated by the network and bank participants in the network. ${ }^{14}$

\footnotetext{
12 The analysis noted above pertains as well to a proprietary network, such as American Express or Discover. A proprietary network balances both sides of the market by simultaneously setting fees to merchants and cardholders. That is, it acts as both a merchant acquirer (that is, engages in a business of signing up merchants and creating incentives for merchants to accept the American Express card) and a card issuer (that is, it engages in a business of attracting cardholders to its cards and creating incentives for cardholders to favor its cards relative to competition). It is clear that as it competes with other merchant acquirers and card issuers for merchants and card holders (or, more generally, for credit card transactions), a proprietary network cannot maximize its profits by saddling either side of the market with the full responsibility for cost recovery (including return on its investments). A strategy of pricing low to merchants likely would require increased prices to cardholders and make its card unattractive to cardholders (and thus costing it merchants in the longrun); while the strategy of pricing low to cardholders likely would make its card unattractive to merchants (and thus costing it cardholders in the long-run). This analysis of business incentives reveals that even a fully integrated proprietary network does not have an incentive to drive the fees to the merchants to "zero" or even to some arbitrary level of allocated costs.

${ }^{13}$ Stephen Ryan of Directorate-General Competition captured this point well when he stated that "a MIF has in practice the effect of dividing the costs of a payment system between two different users - cardholders and retailers." Ryan (2002).

${ }^{14}$ In networks such as Visa and MasterCard, the issuers are the "owners" of the network.
} 


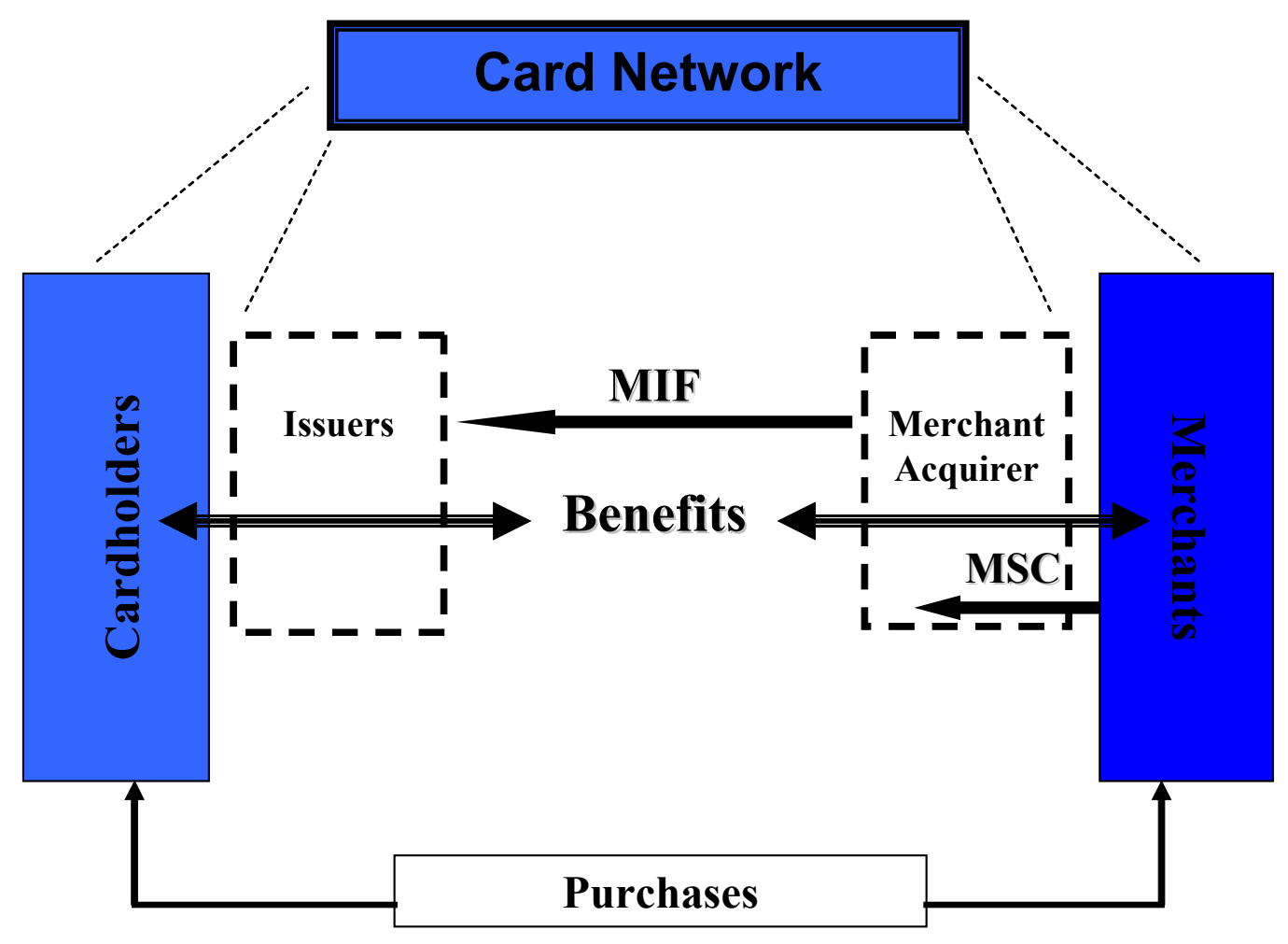

\section{Figure 1: Flow of benefits and payments in a two-sided network}

The effect of changes in the structure of the fees on the overall volume of transactions that run on a given network depends first of all on the responsiveness of transaction volumes to prices charged on each side of the market. Thus, an increase in fees charged to merchants may induce some merchants to disconnect from the network or to steer transactions to cheaper networks (or payment mechanisms). Similarly, an increase in fees charged by an issuer (or a reduction in loyalty payments) will induce some cardholders not to renew the card or to use it less often. In turn, the prices charged on each side of the market will be affected by the magnitude of the interchange fee: a reduction in the interchange fee, for example, may cause acquirers to pass on some of the reduction to merchants who, in turn, may pass on some of that decrease to consumers, which should stimulate transaction volumes. On the other hand, a decrease in the interchange will likely increase the costs of acquiring and using a card thus causing cardholders to cut back on transactions on a given network. Obviously, the overall effect on transactions is hard to predict, as is the overall effect on cardholders and merchants. Again, it is this complexity of effects that throws into doubt the regulator's ability to set an interchange that is "just right" for both sides of the twosided payments market and which maintains forward-looking incentives of networks and banks to invest in new technologies and products and services.

The discussion above, which strips down many of the complexities of the real payments markets, indicates that even if there is perfect competition on both sides of the market (that is, issuers and acquirers charge prices for their services that equal their respective marginal costs and the network or its owners earn just a normal rate of return on its investment), efficient 
pricing may call for cross-subsidizing issuers (meaning positive interchange) or acquirers (meaning negative interchange). ${ }^{15}$

Interchange fees may be used to encourage certain behaviors that enhance network safety or efficiency: for example, interchange can be reduced in exchange for merchants providing additional transaction data, or increased for "card not present transactions" to compensate issuers for enhanced fraud risks arising from transactions that are not conducted by the cardholder in person. In two-sided markets, the level of the interchange determines the split (or composition) of prices for any given level of system-wide per transaction marginal cost. ${ }^{16}$

Given that the costs of operating such networks are largely fixed, efficient pricing also requires mark-ups over marginal cost. Hence, basing fees on "costs" that are arbitrarily allocated to one side of the market or another could affect efficient operations of the network by distorting prices (via the level of the interchange). Moreover, and even assuming that there are no fixed costs associated with the operations of the networks, the recovery of per transaction variable cost(s) has to respect the responsiveness of both sides of the market to the allocation of responsibility for such cost recovery. ${ }^{17}$

Hence, in view of large fixed costs and the pertinent network effects, a sound policy view is that it is unreasonable to expect that the interchange fee can (or should) be set at zero, or at the level of transaction marginal cost, or even at the level that somehow reflects the directly attributable costs of providing the immediate benefits to the merchant from accepting a given card to settle a given transaction as opposed to some other means of payment. Instead, internetwork competition, to the extent that it is effective and potent, should act to protect the interests of the participants on both sides of the market while ensuring that the network earns a satisfactory forward-looking rate of return (adjusted for risk).

These comments suggest that there are fundamental questions whether there is even a need to engage in any sort of regulation of interchange fees. Assuming that there might be some justification for the expressed concern about the levels of these fees, what are the best and most effective policy tools that would bring these fees closer to efficient levels? Again a reminder is necessary: In two-sided markets, pricing at "cost" on one side of the market is likely to introduce inefficiencies and distortions from the perspective of the global effectiveness of the network in generating benefits for all the market participants. ${ }^{18}$ To this end, one must answer such questions as to whether independently set interchange fees are "too high" relative to valid benchmarks; or why isn't enhancing competition among payment systems (or platforms) sufficient, and preferable to bring these fees closer to efficient level; is there some endemic market failure that leads to "excessive" interchange fees and which can only be repaired through direct regulatory intervention; whether on balance regulation as opposed to competition policy would benefit merchants and consumers; and whether the

\footnotetext{
${ }^{15}$ See, Baxter (1983). Some, however, such as Balto (2000), have advocated a zero interchange fee, under the assumption that relevant costs could be recouped from consumers directly.

${ }^{16}$ An analogy may help: assume that it costs a real estate broker $100 \mathrm{hrs}$ on average to match a buyer with a seller. Assume that the opportunity cost of a broker is $\$ 100$ per hour. Hence, the broker has to earn $\$ 10,000$ per transaction (on average) to participate in the market. If all the fees are paid by a seller, sellers fully crosssubsidize buyers; if all the fees are paid for by buyers, the cross subsidy goes in the opposite direction. Neither regime is necessarily optimal. Alternatively, it could make no difference if the composition of fees has no allocative consequences on the relevant (housing) market, but the level does.

${ }^{17}$ In fact, even if there are no network effects insofar as merchants and consumers have signed on to card networks, the level of the interchange will matter for the allocation of transactions between cash (or check) and "plastic".

${ }^{18}$ For example, in Australia, where RBA reforms required significant reduction in interchange, issuers have recovered reduced interchange revenue by increasing fees and reducing benefits to cardholders. See, DataMonitor (March 2003) Interchange in Australia Global Implications.
} 
regulator (be it a competition authority or bank regulator) can determine the proper level of costs at which these fees ought to be set.

In our view, there is no evidence of market failure in the provision of card network services that would warrant (or even suggest) a conclusion that the market should be treated as if it were a natural monopoly and thus ripe for heavy-handed price or cost-based regulation. Indeed, in each and every jurisdiction there is the actuality (or a prospect) of multiple payments networks that vie for merchants and cardholders. ${ }^{19}$ Hence, for direct regulation of interchange to make any economic sense, the regulator has to demonstrate that the marketplace cannot by itself - if functioning properly and absent practices that limit competition - bring interchange and other fees close to a level that is (on the whole) consistent with what would emerge in a vigorously competitive market environment.

\section{$3 \quad$ Evaluating benefits to merchants from card payments systems}

\subsection{Overview of costs and benefits}

Pressure for regulation of credit card interchange fees comes increasingly from merchant complaints about the level of those fees and assertions that merchants receive only limited benefits from the card networks, at least relative to the fees charged. ${ }^{20}$ In addressing these calls for regulation, it is important to distinguish between concerns over the nature of competition among credit card networks and the question whether competitively functioning networks provide substantial benefits to merchants that are in line with the interchange fees that merchants have to recoup from their customers. ${ }^{21}$ Successfully disentangling these two issues shows that merchants realize considerable benefits from credit card network services and that the best policy tool to ensure competitive pricing and benefits to merchants - and consumers - is to promote robust competition among networks rather than to regulate the fees that networks charge.

As noted in the previous section, there is extensive empirical literature on the net benefits to consumers and society from card systems. There is, however, only limited empirical research on the extent to which merchants benefit from the provision of network services. Our review of the literature indicates that empirical studies have largely focused on the societal and consumer benefits from different payments systems, and to the extent they have focused on merchants, have focused too narrowly on the explicit costs to merchants from card acceptance without more detailed assessment of the costs of alternatives and acknowledged only direct, short-term benefits from accepting a credit card for a given

\footnotetext{
${ }^{19}$ To be sure, antitrust regulatory interventions designed to address market conditions that impair competition among payments networks will have the beneficial effects of stimulating network rivalry on price and product dimensions. For example, a recent Department of Justice lawsuit which eliminated Visa and MasterCard rules that prohibited banks from issuing cards on the Discover or American Express networks was designed to stimulate such inter-network competition.

${ }^{20}$ Of course, a merchant will accept a card only if acceptance is preferable to no acceptance.

${ }^{21}$ For example, a recent complaint filed by merchants against Visa and MasterCard and some member banks alleges market power and tying of network services and expresses concerns about levels of interchange fees. US District Court (2005) Photos Etc. Corporation et al vs. Visa U.S.A. Inc, et al, Class Action Complaint, District of Connecticut. Just because merchants have to "pay" the interchange fees, it does not follow that full incidence of these fees actually falls on the merchants.
} 
transaction. As a result, these studies have tended substantially to underestimate the benefits to merchants from card payments system and the costs of the provision of such services. ${ }^{22}$

Moreover, the evidence that is available unfortunately tends to get overlooked in the rhetoric on both sides of the issue of the existence and magnitude of merchant benefits. This section reviews the available empirical evidence with the goal of offering a more comprehensive assessment of merchant benefits and their optimal mode of delivery. There are two key themes to the empirical evidence developed in this paper:

- First, credit card networks deliver to merchants true "network" services that are subject to substantial economies of scale and scope, and, as such, can be provided at lower cost by networks than by the merchants themselves or by third-party vendors of such services.

- Second, credit card networks services lower merchant costs by reducing bad debt, personnel costs, bookkeeping costs, and costs associated with handling and processing customer payments.

We briefly summarize our analyses of each here. Credit card networks deliver to merchants diverse "network" services that are subject to substantial economies of scale and scope, and, as such, can be provided at lower cost by networks than by the merchants themselves. As a starting point to our analysis, we examined recent surveys and studies of payment systems with regard to the services provided to merchants by credit card networks. ${ }^{23}$ These surveys show that merchants place a high value on specific card network services such as card authorization, verification and payment guarantees - that reduce the risk of fraud, facilitate risk management and provide other benefits, detailed below. ${ }^{24}$ Payments networks have developed operational rules that require participants in the network, including merchants, to implement procedures - such as authorization and verification of transactions and handling of data - that reduce the risk and incidence of fraud and have developed statistical and other monitoring tools designed to assure the integrity of the payments network. $^{25}$

Given that merchants value these types of network services - if these services were not provided by the networks, the merchants would have to either provide them themselves or

\footnotetext{
${ }^{22}$ The benefits achieved by network participants are interdependent, and require cost recovery from a variety of sources to sustain the necessary investments in the network. Thus, estimation of benefits or the relative costs of a particular payment mechanism should take into account far more than the relative costs expressly paid for one mode of transaction versus another. This latter is an important point to emphasize as academic papers assessing interchange fees and the efficiency and welfare effects of various outcomes are necessarily based on strippeddown models that do not capture the richness of the markets at issue. Consequently, such models are apt to miss some of the important considerations that bear on the determinants of the interchange.

${ }^{23}$ See, below for a summary of some of the major works surveyed.

${ }^{24}$ See, for example: "Which Security Methods Work Best E-merchants recognize online fraud as a concern, but the majority believe fraud prevention tools can keep it in check?" Research Perspective. http://zones.advisor.com/doc/08087. Merchants in the survey represent large, midsized, and small online sites. Forty-five percent listed annual revenues of more than US\$1 million; 35 percent listed revenues at less than US $\$ 100,000$; and 20 percent reported revenues of between US $\$ 100,000$ and US\$1 million.

${ }^{25}$ The recent thefts of credit card data at merchants such as DSW and Ralph Lauren and credit card processors demonstrate the dangers to the integrity of the payments networks when rules and policies of credit card networks with respect to customer data are not followed. See, for example, "Stores Blame Checkout Software for Security Breaches" (Apr. 27, 2005) Wall Street Journal for discussion of data compromises at DSW, BJ's and Ralph Lauren. See also statements by MasterCard on June 17, 2005 at www.mastercardntl.com and, for example, Zeller, Jr. (2005) at B1 for comments on the substantial breach in data security at Card System Solutions.
} 
procure them from third parties. ${ }^{26}$ Such alternatives are apt to be very costly or even simply not feasible. For example, regarding fraud protection, an important economic question is whether the level of fraud protection that would result from un-coordinated efforts by merchants to obtain such services would be below (or above) the socially optimal levels. ${ }^{27}$ While it is plain that no merchant wants to be a victim of fraud, the merchant's interest in this regard is purely individual whereas the credit card network's interest is to secure global integrity of the payments systems. That global integrity requires, in turn, decisions and "industrial strength" fraud prevention mechanisms that affect millions of merchants. One might think that placing the onus of risk management of credit card transactions on a merchant would reduce the risk of "moral hazard", but this is not so: it is simply impossible for an individual merchant to "manage" credit card acceptance risk. ${ }^{28}$

Hence, in the absence of the "payment guarantee" (that is, credit risk and fraud loss protection) services by credit card networks, each merchant would have the option of buying protection and services from third parties, other than networks, or absorbing these risks itself. Thus, the real question is whether third parties can provide these services at a lower cost and on superior terms than can the networks; it is assuredly the case that "self-provision" would be even higher cost.

The costs to merchants of providing these services themselves (or more plausibly procuring them from third parties) likely would substantially exceed the implicit price merchants pay for them to the payments networks. Even a collection of merchants would not be able to replicate the database of all credit card transactions and the efficacy of global or national credit card networks to formulate risk and fraud prevention and detection techniques and tools that utilize their broad range of information. The networks have access to information about an individual credit card holder and data pertaining to actual credit card activity. By aggregating information from millions and millions of transactions into databases and models, payments networks can and do deploy sophisticated software and statistical techniques to assess patterns of fraud or credit issues. This scale and expertise reduces the costs of risk and fraud assessment, provides for a higher level of skill in management of fraud and credit risk, and by enabling the participation of a large number of merchants and consumers in fraud detection systems, increases the effectiveness and efficiency of monitoring and detection of fraudulent activity.

A credit card network also has the ability to defray the costs of managing the risk control system over a large number of issuers, acquirers, merchants and consumers, resulting in a lower overall cost for each credit verification and fraud prevention and reduction services. The efficiency of the payment guarantee that networks provide to merchants (that is, the guarantee that merchant will be paid for the transaction even if the cardholder is unable to pay or fraudulently evades paying the card issuer) is driven by the scope of data available and the scale that card networks provide. The payment guarantee which is built on interrelationships among issuers and acquirers, and the credit card network, similarly spreads the

\footnotetext{
${ }^{26}$ Third party vendors (for example, Electronic Clearinghouse Inc.) provide check guarantee services, which are comparable to the payment guarantee services provided by credit card networks. These services and vendors, and their costs, are described below.

${ }^{27}$ Every merchant wants to protect itself against fraud. However, taking precautionary steps is costly. More important, a merchant who intercepts a fraudulent card, for example, imposes a positive externality on other merchants (and the network) but disregards those in its monitoring decision. Hence, it is important that networks mandate and monitor compliance at levels that potentially exceed individually optimal levels.

${ }^{28}$ Interestingly, merchants who perceive their clientele to be safer in terms of risks of fraud, would invest less in fraud prevention. This leads to "adverse selection" in the pool of merchants that might obtain fraud insurance or fraud protection services from third parties and thus could undermine the integrity of the system. Pooling of fraud prevention activities at the network level internalizes this free-rider problem.
} 
cost of providing the guarantee over the entire group of card-accepting merchants, resulting in lower costs to merchants, particularly small merchants.

Credit card network services lower merchant costs by reducing bad debt, personnel costs, bookkeeping costs, and costs associated with handling and processing customer payments: We examined three categories of services provided by card networks to merchants to develop estimates of the cost savings to merchants from the provision of these services by networks. (This helps to understand the magnitude of these costs and to assess what these costs would be if merchants had to obtain these services independently.) These three types of services include: ${ }^{29}$

- authorization of card transactions and credit/fraud risk management,

- $\quad$ billing/payment processing, dispute resolution and collection of payments, and

- $\quad$ financing or provision of credit by merchants to their customers.

The next section (Section III B) sets out the empirical analyses of each of these three sets of services, the first of which is directly relevant to the cost savings associated with provision of fraud protection and related services by networks as opposed to individual merchants or collections of merchants (as well as third parties). Section III C then provides a brief summary of the broader empirical literature on benefits from merchant acceptance of cards.

\subsection{Evaluation of card network service benefits provided to merchants}

\subsubsection{Management of card transactions and credit/fraud risk "authorization"}

Among the most important set of services provided by credit card networks is the authorization and transactions and fraud protection and reduction systems. We should note immediately, that authorization services comprise many inter-related services beyond the mere provision of transaction processing and the customary use of the term authorization which typically adheres to the authorization solely of the specific transaction outside of the context of all others). The services provided include:

- Customer and transaction specific information: Timely request for and receipt of the information (from issuers via the network) on the sufficiency of credit or payment ability of the specific customer at the time of the transaction.

- Fraud protection: (1) Screening for fraudulent card usage by the specific customer or a specific card account number, including theft of card or identity theft, and additional verification to ascertain that the cardholder is legitimate and card usage is valid; and (2) More general screening for fraudulent activity to detect patterns of activity and potentially deter increased fraud activity.

\footnotetext{
${ }^{29}$ It should be noted that if the merchant has substantially higher costs of providing or securing these needed services from alternate sources than does the credit card network, the services would be underprovided relative to the socially optimal level (or to the level funded by merchant payments to the networks). The impact of under-provision of services is particularly important because of the private and social benefits from secure and efficient credit card payments systems. For example, in its recent report on cross border dispute resolution, the OECD noted that provision of certain network services, such as dispute resolution, payment guarantees, and enhanced "warranties" and protections for consumers, facilitate both electronic and cross-border commerce. See, OECD (2005).
} 
- Float/immediate payment/payment guarantee: (1) Easy ability to complete the transaction and assure prompt, reliable payment to the merchant for the goods and services purchased; and (2) Merchants who comply with network procedures obtain the payment guarantee for in-person transactions. ${ }^{30}$ This shifts liability and risk from the merchant to the issuing banks, provided that credit card network rules are met.

The services noted above include basic card authorization and validation, address verification, card number verification (additional digits printed on card plastic) and, in Internet sales, password authorization. ${ }^{31}$ The infrastructure required to provide these services goes beyond simply capturing, routing, and settling transactions. In particular, each credit card network provides for databases that sort the relevant information from a broad array of transactions data - and has the ability to update these rapidly to take into account new activity, and apply powerful analytical tools to detect and deter fraud. Networks and the major issuers deploy neural networks or intelligent systems to detect potentially fraudulent activity. ${ }^{32}$ Each of these services requires major investments in its development and its implementation. These costs can be spread across thousands of issuers and millions of merchants thereby engendering benefits to merchants that are linked to the broad reach of the network itself.

The investments made by the networks and the member banks to develop these systems are considerable. Here we examine these costs and compare them to the likely costs of selfprovision or provision by third parties. We also look at the benefits to merchants in the form of reduced risk of loss due to increased fraudulent transactions, which benefits could potentially be foregone if credit card networks were forced by price regulation to reduce their investments in and provision of these services.

\subsubsection{Costs and losses associated with credit risk and fraudulent activity}

Reduction in the provision of services that underlie the provision of payment guarantee by the networks implies that the overall credit and fraud losses that would be borne directly by merchants would surely increase (or some merchants might choose not to accept cards, which

\footnotetext{
${ }^{30}$ Card networks have developed password-based processes for Internet or card-not-present transactions that facilitate efficient shifting of liability to issuers and away from merchants. See, for example, Kucan (2003). MasterCard's SecureCode program offers reduced interchange fees for debit and credit card transactions to complying merchants, who may also be guaranteed payments for online transactions. See, "What does MasterCard Interchange Incentive Mean to Merchants?" (Mar. 2005) Cardinal News. See also, "Visa Announces Breakthrough Anti-fraud Technology" (Jun. 13, 2005) www.presswire.com/cgi-bin.

31 Visa, MasterCard, American Express and Discover each have systems for address verification and card number verifications as well as systems for allowing merchants to examine patterns of activity or to alert consumers as to potential fraudulent activity. See, for example, MasterCard SecureCode ${ }^{\mathrm{TM}}$ which provides a system for consumer authorization on Internet transactions, and an additional service for merchants that enables identifications of fraudulent activity patterns. MasterCard Site Data Protection 10. For description of neural networks, see, for example http://usa.visa.com/download/about_visa/annual_report.pdf?it=search

${ }^{32}$ Networks also provide linkages that are a means of communications with both merchants and consumers about risks, and for centralized handling of communications and information about transactions activity. "As part of their fraud prevention measures, most credit card companies monitor card usage to look for unusual and potentially fraudulent transactions. If an account looks suspicious, a temporary referral is placed on the account which prompts the retailer to call the card company and check that the person in front of them is the genuine customer." "Barclays Responds to Overseas Card Refusals" (Jun. 10, 2003). "Recently there has been considerable success in applying 'intelligent' computing methods that can learn patterns in data for tasks such as finding the patterns of insurance risk or finding the pattern of sales at a retailer. Credit card companies in particular have applied this technology to find patterns that are indicative of fraud and has led to considerable savings." "Business, Technology and Fraud - Overview" (1996) FLARE Project Update, Project Details. http://www.cs.ucl.ac.uk/research/flare/fraud overview.html
} 
has its own detrimental effects as detailed in the previous section) unless merchants would spend more than they currently are expending for network services. Losses incurred by issuers provide a perspective on magnitude of costs that are borne by various participants in the network that could shift to merchants. The chart in Appendix A provides a perspective on the historical costs associated with charge-offs for issuers related to credit and fraud. In order to have a consistent time series, we relied on Nilson Report data (Mar. 2005) for Visa and MasterCard, which show that actual charge-offs declined between 2003 and 2004 and were lower in 2004 than in 2002, despite increases in volumes. ${ }^{33}$ Losses would likely exceed these levels if there were insufficient protections, since these estimates exclude losses that were avoided due to fraud reduction services provided at the network level that were made available to merchants. ${ }^{34}$

\subsubsection{Costs to merchants of fraud prevention}

If networks did not provide the services detailed above, merchants would have to expand considerably their expenditures on fraud prevention. ${ }^{35}$ Current investment levels and survey data indicate that merchants are relying heavily on the investments and services offered by networks and are undertaking only limited investment in complementary activities. ${ }^{36}$ For

\footnotetext{
${ }^{33}$ For example, losses related to credit and fraud were estimated for issuers to be $\$ 788.3$ million in 2004. This represented a decline from the previous year for US issuers, due to increased usage of online authorization and verification systems such as those detailed above as well as the use of "neural networks" to detect fraud. "Credit Card Delinquencies/Charge-Offs" (Mar. 2005) The Nilson Report. Issue 829. Heun (Mar. 4, 2002) provides an extensive listing of initiatives by networks to address security of payments, both generally, and to promote online commerce. Other survey information shows that even with network systems in place, almost 50 percent of online merchants surveyed said fraud had cost their business between $\$ 1,000$ to $\$ 10,000$. Small Business Centre (2004) "Combating Online Credit Fraud," Entrepreneur Business Centre. http://smallbusiness.ninemsn.com.au/article.aspx?id=22100.

${ }^{34}$ See above for estimates of the amount of avoided fraud. While the dollar amount of investments in fraud detection and prevention are not reported, these services have been among the most important areas of activity for networks in the last decade. See, for example, Cocheo (2004) which summarizes systems put in place for credit and debit card transactions by the card associations, and Wasserman (2005) Brandweek which notes only that Visa spent \$297 million on advertising with respect to fraud detection efforts but does not provide estimates of actual investments or expenditures. It is important not to confuse supplementary investments made by merchants for fraud prevention and reduction with the investments made by the credit card networks for these purposes. As an example of the former, we note that Wal-Mart has as invested in supplementary systems that utilize and build on existing payments networks' services. See, for example, its affiliation with Retail Decisions, at Credit and Collections World (Feb. 27, 2002) http://www.creditcollectionsworld. com/industry/022702 1.htm
}

However, it is not likely that merchants with smaller volume than Wal-Mart could efficiently invest in such additional systems, and it is important to recognize that Wal-Mart is building on a foundation of fraud reduction services provided by the card networks. Importantly, it is therefore misleading to conflate supplementary fraud reduction systems with fraud reduction services provided by the network. For example, a recent article in the New York Times reporting on costs borne by merchants today due to fraud neglected to include the fact that these costs are lower than what would otherwise be borne by merchants were credit card network frauddetection services (and payment guarantees) not provided. Zeller, Jr (Jun. 24, 2005). CyberSource, a company that provides electronic payments and risk management systems to a wide variety of merchants and institutions, reports that actual rates of losses per dollar of sales have declined over time relative to the levels that would otherwise prevail due to availability of network services for merchants. "CyberSource Launches Payment Card Industry Security Compliance Service” (Apr. 27, 2005) CyberSource. www.cybersource.com/news

${ }^{35}$ See, for example, Controlling online_credit_fraud.php at pp 4-5, which provides an example of an online merchant expending more money to detect fraud than it lost on actual fraud due to the labor costs associated with detection of about $\$ 25$ versus an average savings of $\$ 20$.

${ }^{36}$ Merchants are offered incentives to participate more actively in card network services as the fundamental means to reduce losses and to achieve enhanced payment guarantee services. A recent survey on card practices by merchants showed that "The survey listed 11 fraud prevention tools, and asked merchants whether they used 
example, when merchants list those services they use to deter fraud, they preponderantly mention services provided by networks: "Asked to rate the tools by how well they reduce online fraud, survey respondents listed the following: address verification systems (68 percent say they work well); real-time authorizations (52 percent); card verification codes (49 percent); and customizing rules (42 percent). The least utilized tool was a custom-built neural network, with only 12 percent of merchants indicating they use this fraud prevention method." ${ }^{37}$ Almost 60 percent of merchants surveyed said they spent less than one per cent of total revenues on fraud prevention. ${ }^{38}$ If merchants were to try to replicate the fraud prevention services provided by networks, they would face higher "per unit" costs of securing acceptable levels of fraud than do the networks. Plainly, networks can spread these costs across thousands of banks, millions of merchants and consumers, and massive volumes of transactions. Moreover, since fraud prevention relies, in part, on constant analysis of huge volumes of transactions, utilization of centralized systems that provide ready and constantly updated authorization and verification improves statistical precision of detection of suspect activities and improves information flows which are critical to effective fraud reduction and detection. ${ }^{39}$

\subsubsection{Enablement of Internet sales}

Internet commerce and the dramatic increase in sales this new sales channel has brought are dependent on the availability of secure payments systems. Sales to unknown customers whose cards cannot be physically inspected require security precautions, including authorization, authentication, etc. As these systems have developed commerce has

them and which they rated as most effective at reducing online fraud. The four most popular tools were address verification systems (about 70 percent say they use them), customer follow-up and real-time authorization tools (both 54 percent), and post-process fraud management tools (43 percent). Interestingly, 54 percent of respondents listed customer follow-up as a tool they use to combat fraud, but only 38 percent viewed it as most effective". http://zones.advisor.com/doc/08087. "Fifty-three percent of merchants report using 5 or more tools to combat online fraud." See pgs.8-10 of: " $6^{\text {th }}$ Annual Online Fraud Report: Online Payment Fraud Trends and Merchants' Response," (2005 Edition) Sponsored by CyberSource Corporation. Conducted by Mindwave Research. Power of Payment Series. http://www.cybersource.com/resources/collateral/Resource_Center/white papers and reports/CYBS 2005 Fraud Report.pdf. See also, "Interview: Largest German Credit Card Issuer on Massive Reduction of Charge Backs Ulrich Riehm (ulrich.riehm@itas.fzk.de) and Arnd Weber (arnd.weber@itas.fzk.de), ITAS, Karlsruhe, Germany, talk to Tilo Schürer (tilo.schuerer@bankgesellschaft.de), Bankgesellschaft Berlin, Germany" which notes that substantial reductions in merchant chargebacks were achieved by the implementation of authorization and compliance programs with card systems.

${ }^{37}$ See, "Which Security Methods Work Best? E-merchants recognize online fraud as a concern, but the majority believes fraud prevention tools can keep it in check," Research Perspective. http://zones.advisor.com/doc/08087

${ }^{38}$ Increase in the cost of preventing fraud or in incidence of fraud on certain types of transactions could significantly repress the volume of such transactions. For example, Internet transactions could fall into this category. On the other hand, by exploiting the available scale and scope economies, payments networks can reduce the levels of fraud to acceptable levels and thus permit socially beneficial transactions to take place.

${ }^{39}$ For example, "Verified by Visa" involves 10,000 issuers in more than 60 countries; see Securing Payments. Visa currently has nearly 18,000 U.S. merchants participating in "Verified by Visa". Visa Annual Report. "By next month, enough of Visa's largest issuing banks will have registered for Verified by Visa to make more than half of its 340 million U.S. cards eligible for this service.” http://www.informationweek.com

/shared/printableArticlejhtml?articleID $=65019$. To the extent that networks have more issuers and cardholders as well as merchants, than would alternative providers of services to merchants, there is a broader base of activity over which to assess information as well as greater scale and scope of operations and base over which to spread costs. Costs are also reduced where common standards are applied across networks. For example, while each network has its own proprietary systems, there are some common standards such as the Payment Card Security Industry Data Security Standard (PCI) recognized by Diners Club, American Express, Discover, $\mathrm{JCB}$, Visa and MasterCard. This does reduce the cost to merchants of handling transactions. See, for example, Punch (2005). 
expanded. ${ }^{40}$ According to the U.S. Census Bureau (2005), 2004 e-commerce retail sales in the U.S. were $\$ 68.9$ billion or $1.89 \%$ of a total $\$ 3.6$ trillion in retail sales and increased considerably in the beginning of 2005. Sales on the Internet are projected to increase to as much as $10-15 \%$ of sales by $2010 .^{41}$ Thus, any significant reduction in Internet sales due to fraud or credit risk concerns could pose significant revenue reductions for those merchants who rely on Internet transactions and inhibit efficient commerce (Marlin, 2004). ${ }^{42}$ In fact, it is hard to imagine at this time Internet commerce without the services provided by credit card networks.

\subsubsection{Merchant costs associated with credit risk management}

Credit card networks provide a tool for checking the ability of a specific customer to pay for the transaction at the time of a particular transaction. These mechanisms also help to determine whether a transaction is a part of a pattern of fraudulent activity. These types of services would somehow have to be provided by other vendors, in the event that networks did not. The merchant would have to develop a way, at a minimum, to communicate with the issuing bank directly, which would entail personnel and time for the merchant (as well as additional time and personnel for the issuing bank), or build its own customer database including relevant financial information. The merchant may find ways to build and maintain a database of repeat customers that may enable it to avoid contacting the card issuer for each transaction. In fact, some of the largest retailers do build their own customer databases. But this alternative would still entail a risk of non-payment because even for otherwise "good" customers, credit-worthiness is not static and circumstances change. In addition, it is unlikely that the merchant would be able to obtain the needed credit information in real time reliably and unobtrusively for infrequent or transient customers, such as tourists or out of town visitors. The merchant would have to use consistent procedures or risk having to turn away business. For smaller merchants, such as boutiques located in a vacation area with a small number of sales personnel, this type of verification would be impractical and cost-prohibitive. Given the practical difficulties this kind of verification provides, merchants may choose to forego verifying credit-worthiness of credit card customers, and face the chance that poor risk consumers will become aware of differences in screening, begin frequenting the less careful merchant more often relative to other locations, and thereby increase that merchant's risk of loss.

\footnotetext{
${ }^{40}$ See, for example Deutsche Bank Research (2004). This article notes that sellers are unlikely to invest in electronic payments infrastructure in a network that had only a few consumers and notes specifically the network advantages to card systems with broader cardholder acceptance.

${ }^{41}$ A recent survey of retailers showed that most believe Internet sales will increase possibly to as much as $10-$ $15 \%$ of total sales. See, "Survey: Retailers Look to the Future" (Jun. 2005) Internet Retailer. www.internetretailer.com. Internetretailer.com. See, http://www.census.gov/mrts/www/ data/ html/04Q4.html. "The Census Bureau of the Department of Commerce announced today that the estimate of U.S. retail ecommerce sales for the first quarter of 2005, adjusted for seasonal variation and holiday trading-day differences, but not for price changes, was $\$ 19.8$ billion, an increase of 6.4 percent $( \pm 2.1 \%)$ from the fourth quarter of 2004." http://www.census.gov/mrts/www/data/pdf/05Q1.pdf “According to the latest figures from Scarborough Research, 47 percent of America's online population shops online" http:/www.nua.com/surveys /index.cgi?f =VS\&art $\mathrm{id}=905356210 \&$ re l=true (Apr. 24, 2001). "The eCommercePulse online survey of 39,000 Web users found that 100.2 million U.S. adults, or 48.2 percent of the U.S. adult population age 18 and over, have purchased online. More than 81.2 percent of all adults with Web access have made a purchase online since they started using the Internet." http://www.clickz.com/stats/sectors/ retailing/article.php /6061 751021

42 "Since deploying Verified by Visa two years ago, CompUSA has practically eliminated fraud-related losses from online sales, says Steve Javery, director of E-commerce for development and integration. The program not only has reduced fraud, it has increased sales by making consumers feel safer shopping online and improved order-processing efficiency." Marlin (2004).
} 
Alternatively, merchants could seek to buy credit verification services from a third party vendor. Regardless of the alternative to network services selected, the alternatives likely would increase costs and time at check-out as compared to the efficacy of the services currently provided by the credit card networks. ${ }^{43}$

A useful proxy for the costs associated with buying credit authorization services from a vendor is the well-established business of check guarantee. ${ }^{44}$ Review of the empirical evidence shows both that check guarantee services also exhibit economies of scale and scope and that the costs of providing these services are roughly comparable - if not somewhat higher - than those for credit card "payment guarantee" services. The costs to a merchant for obtaining check verification and check guarantee services include relevant fees, typically based on a per-item and/or a percentage basis per item and/or transaction (there may also be other monthly fees). Check verification provides a means for the merchant to "verify" the check against a large "negative" database of "bad" check writers and therefore reduce the likelihood of accepting a "bad" check. ${ }^{45}$ Check verification fees, which are assessed on all checks processed, can be in the order of magnitude of $\$ 0.25$ per item and may also include additional fees for minimums or statements, if these are not waived. ${ }^{46}$

Check guarantee services provide a means by which the merchant can obtain the assurance that the amount of a returned check will be covered, if specific rules of the vendor have been followed and the check has been verified. Fees for these services are typically based on a percentage discount fee on all checks accepted by the merchant and can depend on the risks of the merchant or merchant type and are in the range of $1-2 \%$ of the face value of the check, along with a per transaction fee and monthly fees. ${ }^{47}$

These estimates show that the costs for third party provision are likely to include fees that cover all transactions at a given merchant. Moreover, while check guarantee services can be considered as a proxy for the payment guarantee service which is embedded in the merchant discount fee, participation in a credit card network provides the merchant a far wider suite of benefits of services (for example, marketing programs such as the American Express Selects program, an online merchant offers program which can give small merchants the opportunity to reach a far broader range of customers than they could reach on their own, efficient dispute

\footnotetext{
${ }^{43}$ A 1994 GAO study on credit card usage by the U.S. Postal Service found that credit card transactions were processed more quickly than checks. See, GAO (1994).

${ }^{44}$ It is a proxy for the costs, but does not necessarily imply that a vendor of check guarantee services could readily provide credit card guarantee services at lower cost than can credit card networks. Check acceptance has some of the same issues as card acceptance particularly with regard to dealing with consumers from out-of-the merchant's immediate area. Merchants rarely accept checks from non-local customers due to the costs associated with verification as well as the processing and float issues. The Brookings Institution (2004) shows that the costs of implementing such services as check guarantee services can be substantial; see p.x.

45 There are economies of scale and scope in these databases - similar to those in credit card verification services -- with the larger databases of the larger vendors, which include greater coverage of merchants (including more merchants in a given geography) providing fuller and more comprehensive data. Among the companies that provide check verification and related services are: Electronic Clearing House, Inc.; EquiCheck; National Check Trust, Inc.; CheckCare.com; CrossCheck, Inc.; Ezcheckguarantee.com; and Insta-check (Encircle Pay-ments); see http://www.merchantseek.com/checkg.htm and company websites. See also Nilson Report, which lists the largest check guarantee companies in the U.S. - notably, it shows that the largest suppliers of this service have large numbers of merchants that are "enrolled" in the program, indicating that there are economies of scale and scope. "Credit Card Fraud in the U.S." (Mar. 2005) The Nilson Report. Issue 830 .

${ }^{46}$ A useful summary definition of check verification services that can be purchased by merchants and fee structure is found at http://www.merchantseek.com/checkg.htm. See, also Insider's Report on Payments. http://www.greensheet.com/PriorIssues-/030602-/6.htm

${ }^{47}$ See, http://www.merchantseek.com/checkg.htm. See, also Insider's Report on Payments. http://www.greensheet.com/PriorIssues-/030602-/6.htm
} 
resolution services, cash flow facilitation) over and above the specific transactional benefits provided by the "payment guarantee."

\subsubsection{Private sources of insurance fail to be cost-effective alternatives}

Both the Reserve Bank of Australia and the European Commission have endorsed inclusion of the payment guarantee among the services appropriately provided by networks and to be defrayed through the interchange fee. However, more recently, some have questioned this position, suggesting that merchants should be able to purchase insurance privately to cover their credit and fraud risk. We have not been able to identify a product that is currently available that can replicate the payment guarantee services provided by the card networks today. Moreover, it does not appear that a private insurance solution would develop that is comparable in terms of coverage, cost, or efficacy to that provided by the card networks. ${ }^{48}$ Any third party provider of credit and fraud insurance would not be expected to be willing to do so without risk prevention measures comparable to those provided by the networks today, and would be very unlikely to be able to accomplish it at a cost lower than what the networks currently charge as part of the interchange fee. ${ }^{49}$

As a starting point, it is useful to examine the payment guarantee services provided currently by networks. The network payment guarantee covers all merchants, and, subject to certain exclusions for which the issuer is entitled to charge back the merchant, covers merchants for all credit risk and much of the fraud risk with no deductible or cap. Private insurance coverage would likely be much more limited. Some merchants may not be able to secure insurance at all due to underwriting criteria. For example, certain types of businesses may simply be excluded (for example, Internet merchants may find it very difficult to obtain coverage); merchants who operate in a high risk locations may be denied coverage; or the size of an individual merchant or class of similar merchants may simply be too small or not sufficiently lucrative to be cost-effectively underwritten. In addition, any private coverage would include deductibles, caps on the amount of coverage available, and exclusions. These limitations could well result in higher self-insured losses to the merchants. In addition, whereas today the process of collecting under the payment guarantee is straightforward and simple, requiring little effort on the part of the merchant, private insurance would likely represent a much more difficult process to obtain reimbursement for covered credit and fraud losses.

Private insurance is likely to be expensive to provide and hence higher cost for merchants. We illustrate this point by considering the elements of cost associated with private insurance - a premium, an annual deductible, an annual cap on protection and specific exclusions. The premium is determined based on the expected losses plus a mark-up to cover overhead and deliver a reasonable rate of return to the insurer (based on a review of industry practice, likely a mark-up of roughly $30 \%$ ); there would typically be an annual minimum premium. Coverage exclusions would likely apply. For example, transactions for which the merchant failed to obtain authorization or follow risk mitigation procedures likely would not be covered.

Other elements that would increase the cost to the merchant, especially small merchants, might relate to the creation of group programs. For example, because an underwriter would

\footnotetext{
${ }^{48}$ The closest analogy to private insurance for credit card acceptance would be the check guarantee services described above. As with any "insurer" against risk, these service providers need to rely on tools to reduce the known risks - in this case, the risk that a check presented by a merchant's customer will bounce. This risk mitigation is done by accessing a database, analogous to that created and maintained by the credit and debit card networks, which the service providers have had to create and maintain at some cost.

49 The chart in Appendix B compares the relative costs and availability of coverage under an interchange/network approach versus a third party insurance approach.
} 
typically underwrite the risk associated with each individual insured, it would make sense to create group programs for like merchants with similar risk profiles (for example, restaurants). A group program would require a program administrator to process claims and the group members would have to cover that additional cost. Group deductibles and caps can increase the risk that any individual merchant might have inadequate coverage or would have to absorb increased costs associated with its own credit and/or fraud losses.

Private insurers likely would not provide merchants with credit and/or fraud insurance unless there are ways to estimate the magnitude of, and mitigate the risk of loss. As with any insurance, the prospective insurer will need to have the ability to approximate the extent of the risk or exposure to loss, which in turn requires information on the specific merchant's activity, the consumers that frequent that merchant, as well as related activity that could increase or decrease risks. In addition, merchants would need tools to mitigate anticipated risks. Specifically, each merchant would now have to communicate directly with the issuer of each card the merchant accepts in order to secure authorization of the transaction and verification of the card and cardholder. This risk prevention "infrastructure" is what the existing card networks have built over many years and maintain at considerable expense. Private insurers will need to develop comparable risk management systems as a precondition of coverage - either through the ability to access the existing infrastructure and databases of the card networks, or by creating their systems. If the insurers were to require merchants to secure access (either directly or through a third party) to the networks' risk prevention infrastructure, merchants would have to incur costs of doing so, thereby vitiating any putative gains from the unbundling of the payment guarantee from other fees. The alternative of replicating card networks' infrastructure would take both considerable expense and time and is also very unlikely to engender any savings.

Finally, if credit and fraud losses are no longer covered by the payment guarantee, the robust fraud prevention database and mechanisms offered by the networks today would become diluted and less efficient. If the networks are no longer able to charge merchants for the payment guarantee, the networks would be unable to maintain the current extensive infrastructure. As noted above, it is important to recognize that the vast scope of the current network infrastructure plays an important role in fraud prevention. A database that tracks billions of transactions made with hundreds of millions of cards at millions of merchants cannot be replicated with data from only some transactions made at only some merchant locations. Even a very large merchant that opts to self-insure its own credit and fraud losses, lacking access to a global databank, would be unable to identify trends in fraud that they can expect to see in the future and take measures to protect against them.

All of these factors lead us to the conclusion that elimination of the payment guarantee would result in higher costs to virtually all merchants, certain merchants opting out of card acceptance or, worst case unable to continue doing business, and inevitably higher credit card fraud.

\subsection{Billing and collections services, including the value of the payment guarantee}

When a payment is made with the credit card, so long as the merchant has followed the prescribed procedures, the card issuer, not the merchant, assumes the customer credit risk and provides a mechanism for billing and collecting payments from the merchant's customers. Credit card networks provide these services at lower cost and greater efficiency than if individual merchants or even merchant associations provided these services. As mentioned previously, merchants' customers include customers whom the merchant knows well and could easily locate to pursue payment of unpaid bills, as well as transient customers. In the 
case of Internet merchants and Internet sales channels of "bricks and mortar" merchants, purchases are made by customers whom the merchant will never meet and who may be located anywhere in the world. The credit card systems provide greater efficiency overall, because a full month's worth of a consumer's purchases is aggregated in a single billing statement and then paid with a single check (or on-line). Merchants are paid by their merchant acquirer banks for all transactions made on a given day, typically in electronic payments via the ACH system within a day or two of the purchase. This system avoids the time and risks associated with check clearing.

Generally, the merchant is paid for customers' credit card purchases well in advance of the time that the card issuer receives payment from the cardholder. As such, a benefit of card acceptance is the facilitation of the merchant's cash flow. ${ }^{50}$

Without the credit risk, billing and collection services provided through the card networks, merchants would have to take on invoicing and billing as well as collections activity. While merchants may undertake some of these themselves, they would be more likely to use a collection agency, which typically charges between $10-50 \%$ of what is eventually recovered against outstanding claims. ${ }^{51}$ In addition, recourse to a collection agency for payment services does not assure full payment. "According to a survey by the Commercial Collection Agency Section of the Commercial Law League of America, the probability of collecting an overdue account drops to 73 percent after just three months, to 57 percent after six months and to only 29 percent after one year." 52

As noted above, reduction in the volume of fraudulent transactions and the availability of immediate credit verification reduce the risks and costs of non-payment to the merchant. The payment guarantee further reduces the costs to merchants, both directly because the cost of bad debt is more efficiently borne by the issuing banks and indirectly in that it reduces the need of merchants to invest in collection services to obtain payments for services rendered. In the context of Internet transactions, where the charge-offs would accrue to merchants, the provision of address verification, card number verification, and password protection reduce fraudulent activity and bad debt and hence also reduce costs to merchants. ${ }^{53}$

Merchants also benefit from dispute resolution mechanisms. These are particularly valuable for international transaction or for transactions with non-repeat customers. ${ }^{54}$ For example, credit card network rules provide reliable, cost-effective means of dispute resolution in lieu of increased losses and potentially costly litigation. While merchants may well dislike being subject to the risk of chargeback under the credit card network rules, the consumers' ability to raise disputes and receive refunds from merchants from whom goods and services are purchased remotely, over the Internet, or in a one-time transaction during a trip far from home provides consumers with the confidence to make the purchase in the first instance, which enables the merchant to make additional sales.

\footnotetext{
${ }^{50}$ In the absence of credit card network services, merchants would have to develop internal or external collections systems to seek payment for goods sold or services rendered, or alternatively, would have increased write-offs relative to the levels with network services. This suggests increased costs associated with collection activity, which, as noted, tends to recover only a portion of payments and also incurs considerable fees from collection agencies.

51 "Using a Collection Agency." http://www.allbusiness.com/articles/FinanceAccounting/1356-32-1780.html.

52 "Using a Collection Agency." http://www.allbusiness.com/articles/FinanceAccounting/1356-32-1780.html.

53 "Merchant Credit Card Fraud, 31 Ways to Minimize Credit Card Fraud." (Jan. 22, 2005). http://www.wiscocomputing.com/articles/ccfraud.htm.

${ }^{54} \mathrm{See}, \mathrm{OECD}$ report on dispute resolution noting the importance of payment guarantee and dispute resolution functions of payment systems as means to increase confidence and willingness of consumers to make crossborder transactions. OECD Report (2005).
} 
The card networks, card issuers, and merchant acquirers make investments in the operational infrastructure that supports handling such disputes. These benefit all parties to the transaction, not only merchants or customers. The saving in transactions costs and the increased security of transactions engenders cognizable benefits to all that are not easily or meaningfully apportioned among the beneficiaries. It is unlikely that merchants could replicate these services easily using third party vendors and at a lower cost.

All of these factors indicate that credit card networks do provide valuable services to merchants at lower costs than would be available through alternative arrangements, be they self-provision or purchases from non-network suppliers. This does not, however, preclude merchants from supplementing credit card network services with further fraud or credit risk reduction efforts specific to their business or from developing their own ranges of services that "ride" on top of the services provided by networks as well as acquiring and issuing banks.

\subsection{Financing/extending credit}

Credit card issuers extend credit to customers in amounts and for duration chosen by the customer, given the interest rates and other considerations, subject of course to a borrowing cap. The function of extending consumer credit is costly and risky. To the extent that provision of credit (or the option of credit) represents an important aspect of the merchant's business, then, without the card issuer's provision of credit services through the credit card network systems, the merchant would be compelled to provide or obtain comparable services either directly or through vendors who would be willing to provide financing either directly to the customer or to the merchant who would, in turn, extend it to the customer. Merchants, of course, can and do extend credit to their customers but often in connection with a purchase of a single item, such as white goods, for example. The sellers in some industries may be able to factor these future receipts to a factoring firm at a hefty discount, which is the price for shedding the risk of default or payment delay. While this type of financing is feasible and takes place every day, there is no evidence that it is cheaper to the merchant than merchant's acceptance of credit card payment.

Indeed, some critics of the interchange fee have argued that merchants should not pay for credit/financing benefits that credit cards provide to cardholders. This is a narrow view because it ignores the fact that if a merchant can attract valuable customers to the store by extending credit to its customers it will, directly or indirectly, enter into the business of financing transactions. As such, the merchant will incur costs - hopefully lower than the expected benefits - which will have to be recovered from its sales revenue. Hence, insofar as merchants enable credit financing of their transactions by accepting credit cards, proper costbenefit calculus must determine whether merchants would be better-off doing that by themselves or by shifting this function to credit card issuers. On balance, the answer seems to be that shifting that function to credit card issuers is efficient.

The card networks facilitate the provision of these card issuer services for many merchants dealing with customers from a wide range of geographies. In principle, the costs to a given merchant or group of merchants of undertaking the provision of these services will be higher than those of a network given the smaller scale of operations for individual merchants and even groups of merchants as compared to networks and large issuers. ${ }^{55}$ First of all, it

\footnotetext{
${ }^{55}$ We note that certain large companies, such as automobile manufacturers, have established financing companies for this purpose. The same is true for large stores, such as Target, which issue their own store cards and operate the closed loop business themselves. Such an option is likely to be unavailable or unattractive to the majority of merchants. Indeed, over the past few years, most stores have exited this business, selling portfolios to other companies, such as GE Capital, which specialize in issuing private label cards.
} 
simply is impossible for a merchant to extend credit on small and sporadic purchases, given the associated costs. Thus, a bookseller likely will not find it feasible (or cost-effective) to extend $\$ 100$ credit to a parent who is buying books as gifts for his or her children yet, such a parent, may be needing a brief extension of credit to better match income flows with expenditures.

Second, as evidenced by the decline in the usage of store cards, even merchants with major brand names appear to have been unable to implement sufficient incentives to sway customers towards the use of private label or store card to the exclusion of Visa or MasterCard. While even a large merchant may not be able to avoid taking credit or charge cards, such a merchant has at its disposal various tools (including discounts on merchandise aimed at store card users or other promotions) that could be used to shift purchases to other means of payment. One would hypothesize that if using store or private label cards were vastly cheaper than credit, stores would be able to shift usage, at least on the margin. Instead, in recent years, in the US the trend has been to outsource this function to large issuers combined perhaps with co-branding - or exit. Even some of the largest merchants have chosen to exit the private label card business and have outsourced the functions of card solicitation, issuing, marketing, credit evaluation, billing and collection to major bank issuers. For example, in recent months, stores such as Neiman Marcus, Sears and Federated Department Stores sold their store card portfolios and stopped issuing new cards. ${ }^{56}$ Some of the reasons for the switch to outsourcing - lower costs for organizations that handle multiple merchants or wide scope of activity - reveal that there are economies of scale and scope at the issuer level on a variety of functions that are not likely to be achieved by even the largest merchants. The smaller merchants could hardly be expected to be more successful.

\subsection{Broader empirical estimates of benefits related to merchant card acceptance}

The preceding section provided detailed empirical estimates of the benefits from specific network services and estimates of their costs of provision. This section concludes our assessment of merchant benefits with a brief review of the broader empirical literature on benefits relevant to the assessment of policies toward interchange fees.

There is extensive empirical evidence of societal benefits from adoption and diffusion of electronic payments systems. ${ }^{57}$ Recent empirical studies done for European countries show that a country may save $1 \%$ or more of its GDP annually by switching from all paper to all electronic payments. ${ }^{58}$ Recent studies of the social costs and benefits of debit card systems, for example, have refined estimates of the relative costs of various payments in retail locations and shown favorable comparisons of the relative costs of debit as compared to cash even for smaller scale transactions. ${ }^{59}$ These studies demonstrate that there are considerable

\footnotetext{
${ }^{56}$ See, for example, "New Era of Credit" (May 1, 2005) Chain Store Age. which highlights the movement of outsourcing of retail card programs by companies such as Dillards, Saks and Sears, and the importance of scale economies in processing, risk management, and marketing: "Even some of the largest merchants have increasingly switched to outsourcing the credit and issuing function to banks, who in turn can choose among multiple networks now for co-branding and other alternatives."

${ }^{57}$ See, Wells (1996).

${ }^{58}$ Estimates suggest that aggregate nominal bank unit payment cost in 12 European countries may have fallen by approximately $45 \%$ during the 1990 s due to three influences: (1) a declining share of more expensive paperbased payments: (2) a greater realization of improved electronic payment scale economics; (3) lower telecommunication costs due to technical changes (and regulatory changes in some instances). See, Humphrey et al (2003).

${ }^{59}$ Van Hove (2001) provides review of recent report by a Dutch retail trade association on the relative costs of payment alternatives for retailers and found that not all costs of cash are taken into account in examination of
} 
savings to be gained from the introduction of more efficient payments modes, in particular, from conversion from cash and check to card payments systems. The benefits that are achieved from this conversion, however, are not limited to reduced processing costs, and importantly, are not limited to industry sectors with higher-valued transactions.

A recent study by Swartz, Hahn, and Layne-Farrar (2004) provides a very detailed empirical assessment of the scope of benefits and costs across various industry segments in the U.S., although the quantification of benefits is limited to consumer, bank, and central bank benefits; due to difficulties noted by the authors estimating benefits to merchants. ${ }^{60} \mathrm{We}$ reference it here because it provides a perspective on the sources of cost savings that extend beyond the payment or fee associated with the particular method and focuses on benefits extending beyond transactional savings. The Swartz, Hahn and Layne-Farrar paper presents case studies of net social benefits of plastic versus cash or check in grocery stores, discount stores, and electronic stores. The authors scale transactions to take into account the fact that alternative payment methods have varying ranges of average purchase size. They find, for example, that per transaction processing costs for $\$ 100$ of sales in grocery stores are within $10 \%$ for cash and credit/charge (\$2.35 for cash and $\$ 2.56$ for credit/charge) ${ }^{61}$ The authors conduct a comparative benefits analysis by estimating the costs for each party participating in the average small grocery transaction, sum up the various costs (including provision of rewards, check processing, costs of obtaining cash from ATMs, float, etc.) and conclude that debit and credit are lower cost for society than are the paper instruments (cash and check).

While plastic payments may be a low cost payment vehicle for society as demonstrated in these studies, the view has been expressed that cash, and not plastic is uniformly the lowest cost payment vehicle for merchants. This conclusion, however, assumes that costs and benefits are measured very narrowly and do not include cost-savings such as those detailed above, or the costs associated with cash handling for merchants. Swartz et. al note that most recent studies assessing the relative merits of alternative payment mechanisms from the merchant perspective tend to understate the benefits of some of the various payment alternatives to participants, particularly to merchants, because it is difficult to quantify certain of them. ${ }^{62}$ The study therefore concludes that the benefits to society from conversion from cash or paper to card payments are likely understated. ${ }^{63}$ Moreover, merchants, as well as customers who do not use cards, benefit in various ways from the presence of credit cards in

the relative costs of cash versus debit (for example, the time spent receiving and counting cash). The review also notes that if an increase in fees to consumers reduces their tendency to use debit or credit cards then the high fixed costs associated with terminals and other equipment would have to be spread over a smaller number of transactions.

${ }^{60}$ The consumer benefits that are estimated include "float, credit option, record keeping, cashback option, signature debit, reward cards, Discover cards, and privacy".

${ }^{61}$ At p.40, Table 2.

${ }^{62}$ A recent Report by the Board of Governors of the Federal Reserve (Nov. 2004) makes similar points by providing a succinct summary of the literature and evidence of costs and benefits on a merchant basis and a societal basis. The Report concludes that the total costs and total benefits from the use of the particular instrument, either to the merchant, the cardholder, or to the society as a whole are best estimated across all groups and not by focus on any specific cost or payment item. It is noted that the balance of who pays and who pays what is a delicate one and that focus just on processing and operational costs is too narrow. The paper includes available estimates of costs of various payment mechanisms, trends in costs, and documents the nonoperational costs (and benefits) from electronic payments.

${ }^{63}$ In addition, these studies fail to capture all the gains which merchants as a group derive from well-functioning and ubiquitous electronic payments systems. An Ernst and Young 1996 survey of U.S. merchants found that $83 \%$ of merchants surveyed said their sales increased and $58 \%$ said that their profits increased as a result of accepting credit cards. Cited in Chakravorti (2003). 
the economy with positive externalities from frequent card users on light users and even on non-users. ${ }^{64}$

As noted above, the Swartz et. al paper demonstrates that there are considerable savings that can accrue to industries as diverse as discount stores, grocery stores, and electronic stores from acceptance of credit and debit cards. Recent widespread acceptance of credit and charge cards in the quick serve restaurant (QSR) sector and by Business to Business vendors ("B2B") support the premise that the benefits of card acceptance are extensive. Among the card network innovations available to the QSR industry are point of sale solutions created specifically for the industry that provided improved speed of service (by eliminating the requirement for signatures for smaller transactions) as well as a reduction in costs due to decreased risk of theft, cash handling expenses, and manual counting errors. ${ }^{65}$ Card acceptance by B2Bs also demonstrates the value of card acceptance in realizing cost reductions such as float savings and operational savings by eliminating invoicing costs.

\subsection{Conclusions concerning benefits}

The benefits merchants receive from the provision of credit card network services are considerable. The substantial benefits that are provided include the reduced overall cost of fraud, the more efficient allocation of financial risks as between the merchant and issuers, improved liquidity (prompt payment) of the merchants, as well as opening new retail channels. These services facilitate many aspects of merchants' sales, reduce costs to merchants, and can be provided by credit card networks at a cost significantly below that likely to be achievable by merchants, particularly small merchants, on their own or from other sources.

Critics of interchange fees narrowly focus on a small set of benefits that merchants derive from card acceptance and conclude that merchants "overpay" relative to the benefits which accrue to them. It is not exactly clear what this criticism means other than, perhaps, the level of the interchange is too high relative to some second-best benchmark. ${ }^{66}$ Such a second-best

\footnotetext{
${ }^{64}$ Recent studies, for example, suggest that non-card users benefit from the use of cards by other customers because card acceptance may facilitate a faster checkout compared to payment by check; or there may be reduced collection costs from card acceptance as compared to checks, which in turn should lower prices at the checkout line. It is important to realize that even a customer who on any given occasion may not "pay with plastic", derives value from the presence of the credit and debit terminals at merchant locations. We can think of this value as a "real option" - that is, an option to pay with plastic when such payment is preferred to an alternative (cash or check). Indeed, such customer benefits from the fact that other customers are frequent users of plastic and by virtue of the fact that their demand for credit or debit transactions has compelled merchants to install point-of-sale hardware and software that would make such transactions possible. There are a number of benefits that cards do provide to consumers including a widely accepted form of payment, rewards, liquidity and an efficient dispute resolution system, which gives consumers confidence to do business with merchants with whom they have not had prior experience and will never meet (such as merchants who do business solely on the internet or via mail or phone sales). Credit cards provide consumers a secure, reliable and convenient means of payment. See, Chakravorti (Jul. 2003) at 52. In addition to float, consumers often benefit by receiving extended warranties, rebates on purchases, cash discounts and travel awards. Chakravorti (1997). Credit cards serve as a payment device in lieu of cash or checks for "millions of routine purchases as well as for many transactions that would otherwise be inconvenient or perhaps impossible..." See, Durkin (2000), Credit cards have also become the primary source of unsecured open-ended revolving credit, replacing the installmentpurchase plans that were important to the sales volume in many retail stores in times past.

${ }^{65}$ Given the size of this industry sector, cost savings from diversion to electronic payments of the type assessed in the case studies are bound to be considerable.

${ }^{66}$ When a card issuer provides incentives to encourage consumers to use cards more frequently, card transactions volumes at merchants generally increase. This increased use of card payments spreads the fixed costs across a broader base of transactions. Thus, rewards to consumers in a two-sided market are likely to increase volume of card transactions at merchant locations. A recent article by Hayashi (2005) presents a model
} 
benchmark may be very difficult to construct and implement if only because doing so requires such a substantial amount of information. Perhaps a better framework for assessing the magnitude of these (net) benefits is to ask whether the fees that merchants pay are consistent with the costs that merchants would have to incur if some of the services that issuers and payments networks provide - including extension of credit and the payment guarantee - were provided by the merchants themselves (or procured from sources other than the networks) in response to competitive pressures from other merchants and consumers. Put another way, if the various services that merchants now obtain from the networks were unbundled and merchants were to self-provide them, or procure them from third party vendors, would the merchants incur lower costs, would they match up their needs with the available services and would they receive the same level of service obtained today from card networks?

In particular, even assuming that there is some public policy rationale for regulating interchange fees, which we think there is not, the public policy assessment of a "third best" level of fees should reflect a full assessment of benefits that accrue to the merchants as well as a careful analysis of the distortions that may inadvertently occur if cost-based regulation does not allow for efficient and sufficient recovery of costs of investments in the payment systems. We turn to that in the next section.

\section{$4 \quad$ Final remarks}

Extensive regulatory intervention into the operations of the credit card networks is not in the public interest and is not warranted. Such intervention can undermine the incentives of the networks to maintain current levels of service and to deliver new and improved services to merchants and consumers. Moreover, it can impede development of these networks in jurisdictions in which adoption of credit and debit cards is far from ubiquitous. ${ }^{67}$ In developing markets, the fixed costs of the networks are spread over a smaller base of transactions, thus potentially leading to higher prices for the provision of these services. However, regulation will not increase penetration and will not stimulate transaction volumes, thus making it more difficult - not more likely - for networks to lower the costs to consumers and merchants. The unintended effects of regulation cannot be ignored in assessing whether regulation will achieve its stated objectives.

\subsection{Conditions for price regulation are not met}

Price regulation - particularly price regulation that sets fees or fee caps based on some but not all measures of the costs of service - is unwarranted, inherently difficult to implement in a manner that does not distort decisions, and prone to create significant inefficiencies and harm to an otherwise workably competitive marketplace. While the payments systems markets are complex, they do not meet any of the conditions that would warrant price regulation. In general, conditions that warrant such heavy-handed interventions are rare and are not at all satisfied in the credit card networks. Review of the regulatory regimes around the world indicates that such direct intervention into price-setting has been triggered in two

\footnotetext{
that examines under a variety of assumptions whether merchants would accept cards even if the associated fees were in excess of the benefits to merchants. The Hayashi paper sets out a model in which to evaluate the benefits and relative costs of card payments predicated on the "transactional" costs and benefits to merchant and consumers from card transactions relative to the relative costs associated with card payments. It is important to note that this paper is not opining that the overall fees are in excess of actual benefits to merchants.

${ }^{67} \mathrm{See}$, for example, Mexico, which has a relatively low rate of electronic payments.
} 
generic situations: One is the presence of natural monopoly and the other is the presence of an "upstream" bottleneck input that is essential to the provision of a "downstream" service. Even in these circumstances, however, cost-based price-regulation presents significant challenges, not the least of which stem from endemic difficulties in measuring the costs against which prices should be set.

These market contexts in which regulation has been considered and implemented do not apply to the market conditions in the credit card industry or the rationales claimed by those who advocate regulation of interchange fees. Moreover, it is important to note that current economic and public policy thinking is that even where the fundamental conditions for regulation of prices (to consumers or to competitors) may be present, such regulation does not come without a social cost. Setting aside the administrative costs of the regulatory system, there are other costs that have to be accounted for. For example, the regulator can be "captured" by interest groups that could be direct beneficiaries of potentially distortionary regulation and, instead of setting a "socially optimal" fee, the regulator may set the fee that favors a particular constituency.

\subsection{Complexity of applying cost-based regulation to payments systems}

In the two-sided markets in which credit card and debit networks function, the level of the interchange fee is only one part (and a red herring, at that) of a broader public policy issue that the regulator must consider. A fundamental issue in such two-sided markets, is really how to allocate the cost recovery burdens and responsibilities between the two sides of such markets The merchant acquirers (who charge fees to the merchants who, in turn, interact with their customers) and the card issuers (who charge fees to cardholders who, in turn, are customers of the merchants).

In the markets for the provision of credit and debit card network services, the general rule still applies that responsiveness of demand (that is, its elasticity) to changes in the pertinent prices is the controlling economic force that affects the fees that can be charged. What is different is that the pertinent elasticity is built up from the behavior of economic agents on the two sides of the market the network spans. However, what is key is the fact that these two-sided networks have different economic actors on each of the networks' sides, each having different economic valuations (as reflected in their willingness to pay) of the services the networks provide. ${ }^{68}$

If the network has both variable (per transaction) costs and fixed costs (which are in fact substantial), then basic economics establishes three things. First, pricing any service at variable (marginal) cost is a road to ruin and, second, these fixed costs have to be recovered in a manner that least represses the total volume of output of the desirable good (here output can be measured to the first approximation as the total volume of transactions running on the networks). And, third, in the context of two-sided markets, the allocation of responsibilities for cost recovery between the two sides of the market should be done in a manner that reflects the network externalities engendered by the mutual interdependence of market participants. $^{69}$

The simple point is that it is already a complicated exercise to determine cost-based prices that a regulated utility can charge for the services it sells to end-users. It is an even more complicated exercise to determine the proper cost base for pricing access to a

\footnotetext{
${ }^{68}$ Interestingly, credit-card holders, like the credit-card networks, also span both sides of the "market": these card-holders are competed for by the financial institutions (credit-card issuers) and by the merchants who offer attractive prices for their wares and convenient payment options.

${ }^{69}$ For more technical paths to this same basic insight, see the papers by Schmalensee (2002) and Rochet and Tirole (2002).
} 
bottleneck that a supplier can charge to the downstream users. And it is incomparably more difficult to determine what should be the rates that a network in a two-sided market ought to charge the parties on both sides of the transaction. Moreover, the simple notion that there is any one group that should be responsible for cost recovery is plainly flawed as a matter of economics since parties on both sides of the market respond to economic incentives (as embodied in various fees and benefits) and thus together ought to be responsible for the recovery of costs. Moreover, there is a substantial risk associated with regulation particularly if it reduces the incentives for sufficient network investments. ${ }^{70}$

Hence, assuming even that regulation is possible or desirable, "cost-based" pricing of interchange is a prescription for inefficiency inasmuch as it assumes that costs can be readily calculated, that proper rates of return can be ascribed to the investments (correcting for risk), and that such cost-based rate charged to merchants could somehow properly reflect the demand responsiveness on both sides of the two-sided market and the various externalities that each side bestows on the other.

\subsection{The policy alternative - competition policy}

Policy-makers already have at their disposal tools that can promote efficiency and competitive pricing without unnecessary regulation. Reliance on competition principles and on competition itself can deliver benefits to merchants and consumers. There are recent examples that demonstrate that more "surgical" elimination of artificial impediments can open up the marketplace to foster outcomes that can yield consumer benefits. These have included policies and other efforts to eliminate artificial impediments to entry and expansion and to promote greater inter-network competition. ${ }^{71}$

In sum, economics theory and experience with regulatory interventions in many countries indicate that heavy-handed cost-based regulation of prices is the public policy of last resort. It should only be adopted when there is a cognized market failure of the sort that cannot be remedied by less interventionist means. There is no evidence that such market failure exists in the markets for the provision of credit or debit card network services. The most appropriate role for competition policy in the realm of payments systems is to promote and ensure market conditions that foster vigorous competition among payment networks and among different means of payment and to remove unnecessary impediments to such competition at the merchant and cardholder level. Arbitrary and artificial allocations of responsibilities for costrecovery to merchants based on the narrow definitions of "benefits" that inure to them from credit and debit payment systems is not consistent with either economics or sound public policy. Empirical evidence on the benefits from innovation and investment in card networks shows that society, consumers, as well as merchants benefit directly and indirectly from such investments.

\footnotetext{
${ }^{70}$ See, Ordover and Wang ( 2005).

${ }^{71}$ For example, in the area of government enforcement, the U.S. Department of Justice sued Visa and MasterCard with a resulting decision by the U.S. District Court that removed restrictive association by-laws and policies that prevented U.S. banks from issuing cards on the competing American Express and Discover networks. As a result of the ruling in that case, the American Express and Discover networks have an opportunity to increase in size, both in terms of cards in force and accepting merchants, and become more effective competitive constraints on the Visa and MasterCard networks. For example, American Express has entered into agreements with MBNA, Citibank, Juniper/UBS and USAA to offer new and innovative cards that are accepted on its global network and Discover has entered into some partnerships as well.
} 


\section{$5 \quad$ References}

Balto, David (2000) "The Problems of Interchange Fees: Costs Without Benefits," European Competition Law Review, 81(1): 50-81.

Baxter, William F. (1983) "Bank Interchange of Transactional Paper: Legal Perspectives," Journal of Law and Economics, 25: 541-588.

Board of Governors of the Federal Reserve System (Nov. 2004) Report to the Congress on the Disclosure of Point-of-Sale Debit Fees.

Breyer, Stephen (1982) Regulation and Its Reform, Harvard University Press: Cambridge, MA.

Census Bureau (2005) http://www.census.gov/mrts/www/data/html/04Q4.html Feb. 24

Census Bureau ( 2005) http://www.census.gov/mrts/www/data/pdf/05Q1.pdf May 20

Chakravorti, Sujit (1997) "How Do We Pay?" Financial Industry Issues. First Quarter. Federal Reserve Bank of Dallas.

Chakravorti, Sujit and Ted To (2003) "A Theory of Credit Cards." Working paper, Federal Reserve Bank of Chicago.

Cocheo, Steve (2004) "Debit's Downside," ABA Banking Journal, American Bankers Association.

Department of Justice, "Antitrust Division Policy Guide to Merger Remedies," (Section III.A). http://www.usdoj.gov/atr/public/guidelines/205108.htm

Deutsche Bank Research (2004) “Digital economy and structural change,” No. 44.

Durkin, Thomas A. (2000) "Credit Cards: Use and Consumer Attitudes, 1970-2000," Federal Reserve Bulletin.

EU Institutions (2002) "Commission exempts multilateral interchange fees for cross-over Visa card payments," EU Institutions press releases. July 24 http://europa.eu.int/rapid/pressReleasesAction.do?reference=IP/02/1138\&

format $=$ HTML\&aged $=0$ \&language $=$ EN\&guiLanguage $=$ en

Evans, David, and Richard Schmalensee (2005) "The Economic of Interchange Fees and Their Regulation: An Overview," Mimeo.

Gans, Joshua S. and Stephen P. King (2003) "Approaches to Regulating Interchange Fees in Payment Systems," Review of Network Economics, 2: 125-145.

GAO (1994) "US Postal Service: Proposed Policy to Accept Credit and Debit Cards Makes Sense Conceptually." 
Gonenc, Rauf, and Maria Maher and Giuseppe Nicolette (2000) "The Implementation and the Effects of Regulatory Reform: Past Experience and Current Issues," Economics Department Working Papers No. 251.

Hayashi, Fumiko (2004) "A Puzzle of Card Payment Pricing: Why are Merchants Still Accepting Card Payments?" Mimeo. Payments System Research, Federal Reserve Bank of Kansas City.

Heun, Christopher T. (Mar. 4, 2002) "Fear of Fraud," Information Week. http://www.informationweek.com/shared/printableArticle.jhtml?articleID=6501819.

Horovitz, Bruce (2004) “McDonald's Joins Pay-with-Plastic Trend,” USA Today.

Humphrey et al. (2003) "Working Paper No. 03-16: Cost Savings from Electronic Payments and ATMs in Europe," Federal Reserve Bank of Philadelphia.

Information Policy Institute (2003) "The Fair Credit Reporting Act: Access, Efficiency, and Opportunity." Presentation to FTC, Washington, DC. http://www.ftc.gov/bcp/workshops/infoflows/present/turner.pdf

Kucan, B. (2003) “Online Credit and Debit Security Report,” Data Monitor.

Marlin, Steven (2004) “I.D. Under Lock and Key,” InformationWeek.

Morrison, Steven and Clifford Winston (1995) The Evolution of the Airline Industry, The Brookings Institution Press: Washington, DC.

Moulds, Richard (2003) "Securing Online Payments." http://www.netsecurity.org/article.php?id=450

OECD (1999) "The Economic and Social Impact of Electronic Commerce: Preliminary Findings and Research Agenda," OECD Report. http://www.oecd.org/dataoecd/3 /12/1 9448 $\underline{\text { 83.pdf }}$

OECD (2005) OECD Workshop on Consumer Dispute Resolution and Redress in the Global Marketplace Background Report.

OECD (2005) OECD Workshop on Consumer Dispute Resolution and Redress in the Global Marketplace. Proceedings of a workshop held April 19-20, Washington, DC.

Ordover, Janusz and Yijia Wang (2005) "Interchange Fee Regulation and Network Investment," Competition Policy Associates, Mimeo.

Punch, L. (2005) "Internet Retailers are Coming Around to the Card Companies Security Programs," Internet Retailer.

Purcell, Phillip (2000). Prepared Testimony, Hearing on Competition and Innovation in the Credit Card Industry at the Consumer and Network Level, Senate Banking Committee $\begin{array}{lllll}\text { Subcommittee } & \text { F } & \text { Financial } & \text { Institutions. }\end{array}$ http://banking.senate.gov/00 05hrg/052500/purcell.htm

Reserve Bank of Australia (2003) Reforms of Credit Card Schemes in Australia. 
Rochet, Jean-Charles, and Jean Tirole (2002) "Cooperation among Competitors: Some Economics of Payment Card Associations," Rand Journal of Economics, 33: 549-570.

Ryan, Stephen (2002) "Clarifying the application of the competition rules to card payments systems: the Commission's exemption decision on the Multilateral Interchange Fees of Visa International," Competition Policy Newsletter, Number 3: 32-33.

Schmalensee, Richard (2002) "Payment Systems and Interchange Fees," Journal of Industrial Organization, 50: 103-122.

Schmalensee Richard and Robert Willig, Ed. Handbook of Industrial Organization, Vol. 2.

Swartz, Daniel, Robert Hahn, and Anne Layne-Farrar (2004) "The Economics of a Cashless Society: An Analysis of the Costs and Benefits of Payment Instruments," AEI-Brookings Joint Center for Regulatory Studies.

Van Hove, Leo (Jul. 2001) "The Price of Cash Revisited," ePSO Newsletter, No. 8. http://epso.jrc.es/newsletter/vol08/8.html

Vickers, John (2005) "Public policy and the invisible price: competition law, regulation and the interchange fee." http://www.oft.gov.uk/NR/rdonlyres/2673F9E4- 4BBD-4314-A84692D203E34 483/0/spe040 5.pdf

Wasserman, Todd (2005) "Visa Charges Ahead On Security Front," Brandweek.

Wells, Kirsten E. (1996) “Are Checks Overused?” Quarterly Review. Fall. Federal Reserve Bank of Minneapolis.

Zeller, T. Jr. (2005) “To Catch A Thief,” New York Times. 


\section{Appendix A - Empirical estimates of chargeoffs}

\begin{tabular}{|c|c|c|c|c|c|}
\hline Year & 2000 & 2001 & 2002 & 2003 & 2004 \\
\hline $\begin{array}{l}\text { V/MC Net } \\
\text { Chargeoffs for } \\
\text { Credit Cards } \\
\text { (billions) }\end{array}$ & $\$ 25.37$ & $\$ 31.89$ & $\$ 37.46$ & $\$ 39.03$ & $\$ 35.61$ \\
\hline Credit & $\$ 24.66$ & $\$ 31.14$ & $\$ 36.69$ & $\$ 38.34$ & $\$ 34.98$ \\
\hline Fraud & $\$ 0.67$ & $\$ 0.75$ & $\$ 0.77$ & $\$ 0.69$ & $\$ 0.63$ \\
\hline $\begin{array}{l}\text { Total Credit } \\
\text { Card } \\
\text { Transactions* } \\
\text { (billions) }\end{array}$ & 9.27 & 10.1 & 10.8 & 11.3 & 12.4 \\
\hline $\begin{array}{l}\text { Dollar Value } \\
\text { of Credit Card } \\
\text { Transactions* } \\
\text { (billions) }\end{array}$ & $\$ 768.29$ & $\$ 818.15$ & $\$ 880.95$ & $\$ 945.73$ & $\$ 1,044.41$ \\
\hline $\begin{array}{l}\text { Total Credit } \\
\text { Cards } \\
\text { (millions) }\end{array}$ & 453.0 & 493.4 & 525.3 & 556.3 & 566.8 \\
\hline $\begin{array}{l}\text { Total SE's } \\
\text { (millions) }\end{array}$ & 3.5 & 3.6 & 4.0 & 4.1 & 4.6 \\
\hline
\end{tabular}

Source: Nilson Reports 738, 760, 784, 805, 828

- Purchase transactions (excludes cash) 


\begin{tabular}{|c|c|c|}
\hline Features & $\begin{array}{l}\text { Credit/Charge Card Network } \\
\text { Payment Guarantee }\end{array}$ & $\begin{array}{l}\text { Private } \\
\text { Insurance }\end{array}$ \\
\hline Cost & $\begin{array}{l}\text { Portion of interchange or merchant service fee } \\
\text { attributable to cost of payment guarantee }\end{array}$ & $\begin{array}{l}\text { Expected Losses }+30 \%, \\
\text { Minimum premium } \\
\text { For Group programs a program } \\
\text { administrator/third party } \\
\text { administrator would be } \\
\text { necessary, adding more cost. }\end{array}$ \\
\hline Deductible & None & Yes \\
\hline $\begin{array}{l}\text { Amount of } \\
\text { Protection }\end{array}$ & $\begin{array}{l}\text { Unlimited, only cap is the volume of } \\
\text { transactions submitted }\end{array}$ & $\begin{array}{l}\text { A specified limit would apply } \\
\text { per merchant or group } \\
\text { per loss/per year. }\end{array}$ \\
\hline Exclusions & $\begin{array}{l}\text { Credit - failure to obtain authorization } \\
\text { Fraud - failure to obtain authorization, } \\
\text { accepting altered cards, validate mag stripe } \\
\text { on card; if card not presented to merchant, } \\
\text { validate card security code }\end{array}$ & $\begin{array}{l}\begin{array}{l}\text { Same as for } \\
\text { guarantee }\end{array} \\
\begin{array}{l}\text { Additional, for } \\
\text { Internet Sales }\end{array}\end{array}$ \\
\hline $\begin{array}{l}\text { Required Risk } \\
\text { Management } \\
\text { Processes }\end{array}$ & Same as exclusions & $\begin{array}{ll}\text { Card authorization } & \text { and } \\
\text { verification, availability } & \text { of } \\
\text { funds } & \end{array}$ \\
\hline Who is covered & All merchants & $\begin{array}{l}\text { Insurers would select which } \\
\text { merchants/groups they are } \\
\text { willing to underwrite. Some } \\
\text { merchants would not be } \\
\text { offered insurance, for example } \\
\text { internet merchants, smaller } \\
\text { merchants, merchants in more } \\
\text { "risky" environment }\end{array}$ \\
\hline Other & & $\begin{array}{l}\text { For group programs, } \\
\text { merchants would share one } \\
\text { insurance limit. The other } \\
\text { members of the group } \\
\text { Might use up this limit. Early } \\
\text { claimants would absorb } \\
\text { aggregate deductible. }\end{array}$ \\
\hline
\end{tabular}

